\title{
WHAT WE LEARNED FROM THE 2009 FINANCIAL CRISES IN EMERGING COUNTRIES
}

\author{
Robert BOYER*
}

Paper prepared for the conference "Financial Stability and Growth" Sao Paulo, March 22-23, 2012

\footnotetext{
*Institut des Amériques 175, rue du Chevaleret 75013 PARIS (France) robert.boyer@ens.fr
} 


\section{INTRODUCTION}

During the quiet times of stable and rapid growth, economists tend to think that they totally master their discipline and that they have converged towards a correct understanding of macroeconomic dynamics. Similarly policymakers do not engage into any major institutional reform because they extrapolate the current performance over a long period: why should they announce possibly unpopular measures whereas the economy is in such a good shape? This was precisely the intellectual and political context during the Great Moderation of the early 2000s: the quality of economic policy and the sophistication of the modern financial systems had provided a rather rapid growth with low inflation. Economic crises seemed to belong to the past or to be relegated to few exotic and distant countries that refused to adhere to the conventional wisdom of the Washington Consensus.

The collapse of Lehman Brothers and its aftermath were a painful wake up call for the economic profession and the beginning of an uncertain muddling through in search for relevant anti- crisis policies and long term reforms that would prevent the repetition of a near melting down of the American financial system and world trade. The severity and diffusion of this crisis call for a reassessment of macroeconomic and financial theories that generally displayed a quite poor analysis of crises, assumed to simply result from adverse exogenous shocks. De facto, the repetition of financial crises in emerging countries since the mid $80 \mathrm{~S}$ should have called the attention of economists and policy makers, because they already displayed most of the components of the present difficult times: large inflows of foreign capital and sudden stops, real estate speculative bubbles and their bursting out, rapid contagion to the world economy and poor efficacy of national strategies in the context of financial globalization.

This chapter aims at collecting the major stylized facts that emerge from the observation of such episodes in emerging economies in order to derive some key lesson, first concerning the role of financial globalization and innovation (section II), second about the forces that shape the international system (III). It is then argued that the relations between Asia and Latin America may define, in the long run, a new pattern for the world economy (IV). Similarly, policy makers and economists have finally learnt from their bad handling of previous crises and they have pragmatically converged towards a common set of basic principles, implemented differently according to the domestic context (V). Nevertheless, the related improvements in crisis prevention and cure suffer from a major weakness: they are not supported by a fully-fledged new theory of development that is to be elaborated in order to replace the failed paradigms and provide intelligibility and guidance in the conduct of institutional reforms (VI).

\section{THE ROLE OF FINANCIAL GLOBILISATION AND INNOVATION IN THE 2009 CRISIS}

Back to the 80s, repressed financial systems were supposed to define one of the obstacles to development and equity. Therefore the progressive international and then domestic financial deregulation was welcome by most economists: international credit would mitigate domestic recessions and help in financing productive investment and thus foster growth and higher standards of living. It is not precisely that has been observed and this gap between expectations and final outcomes bring three lessons. 


\section{II.1 - It is especially dangerous to build a growth strategy upon a cumulative indebtedness in foreign currencies}

This is not at all a new finding that would pop out of the spectacular collapse of Ireland and Iceland in 2009. It dates back from one of the first emerging economies: the two oil shocks turned Mexico into a very attractive borrower for developed countries banks. The external debt exploded from 20\% of GDP in 1973 to $83 \%$ in 1983 at the eve of the crisis of 1984 (Moreno-Brid and Ros, 2010). The government had to nationalize the banking system and put in place a strong control of change.

In between these two quite distant episodes, the list of countries plagued with the same pattern is quite long. Most Latin American countries have experienced it during the 90 s and this process culminates with the systemic collapse of Argentina in the winter 2001-2002 after a depression that started in 1997. The 1997 Asian crisis and the 1998 Russian default follow, but it not the end of the story, since the Eastern and Central European countries that freed themselves from the soviet type regimes have fallen into the same trap: the Baltic states, Hungary, Romania, Ukraine, Bulgaria and finally Croatia have ended up into an unsustainable external debt denominated in foreign currencies (table 1 infra).

By contrast when the size of external credit in foreign currency is carefully assessed or limited by a previous default, the macroeconomic stability seems easier to maintain. For instance, after 2003 a new growth pattern has emerged in Argentina, based upon a competitive exchange rate, a larger tax basis and last but not least an increase of domestic saving (Boyer, Neffa, 2007). The long run viability of this new institutional configuration is still to be searched for, but the comparison with the currency board period is quite enlightening. China is another example of control of capital inflows since the governments have taken into account the lessons from the 1997 Asian crisis.

\section{II.2 - Most governments have learnt from the succession of their own financial crises but this lesson has not been taken into account elsewhere}

The comparison of the two columns in table 1 suggests this interesting hypothesis.

On one side Asian countries, such as Indonesia, South Korea, have been struck by the major 1997 crisis and they have adopted various strategies in order to prevent its repetition, especially by accumulating reserves in foreign currencies and some others, such as Malaysia, by a control of entry of capital. They thus reduced drastically their indebtedness in foreign currencies and they went through the 2009 crisis far better than in 1997. The evolution is similar pour most Latin American countries (Argentina, Brazil, Mexico) since the repetition of crises of external capital account has led to a progressive and pragmatic aggiornamento of their exchange rate 
regime and public finance and a deeper financial intermediation at the domestic level, either by choice or as a consequence of a previous default.

On the other side the economies that recently joined the international economy and played the game of financial globalization have reached very high ratio for the share of credit labeled in foreign currencies. They seem to have totally ignored the pattern observed elsewhere because they imagined that their situation was different and/or that times had radically changed from the 90s to the 2000s. This belief in a form of "national exceptionalism" has been quite costly for these societies that were severely hit by the freeze of the world financial system. Benchmarking is quite fashionable in quite any domain with a major exception, the understanding of the process that leads to crisis and the methods in order to prevent them.

Table1: The contrast between the economies that had already experienced sudden stops and the others

This second lesson is confirmed by a review of the long run history of economic, financial and exchange rate crisis (Kindelberger, 1978; Garber, 2000; Boyer et Alii, 2003; Boyer, 2008). Each generation of financier, economist and policy maker tends to think that their epoch is so modern and different from their predecessors that the same process of excessive credit will not end up badly as in the past. This absence of long run memory of crises is quite intriguing for the academic analyst: "this time is different "captures very well this amnesia and absence of learning (Reinhart and Rogoff, 2009).

\section{II.3 - Be careful in adopting the latest and highly complex financial innovations: a chance for the majority of lagging emerging countries}

The Latin American crises of the 80s and those of Asia in the 90s have generally been interpreted as deriving from archaic regulatory systems and the absence of diffusion of modern economic institutions, including the most sophisticated financial innovations. Similarly in the 2000 s, a slower European growth was attributed to the lag first in adopting information technologies, second in accepting the equivalent of subprime credit and an intensive use of derivatives. Standard economic theory is built upon the implicit premise that any innovation, technical, organizational or financial, is good for economic efficiency and welfare.

The sequence of events after September 2008 largely contradicts this vision. The economies that had not adhered to financial innovation led growth are in far better shape than others. It might be wise to wait and see before relying upon new, complex and somehow mysterious instruments that may turn quite detrimental for macroeconomic stability. Just some examples will be given here. Canadian authorities have kept intact the coherent and strict regulatory system that governs real estate credit. Of course Canada was affected by the collapse of world trade and freeze of international credit, but no toxic derivatives were created and foreclosures have been quite limited. More generally, the recovery has been more vigorous and less artificial in countries where commercial banks are the basic provider of credit to households and firms (Germany, South Korea, Japan, China,...) compared with those dominated by direct finance and the surge of highly complex financial instruments (United States, United Kingdom,...).

In retrospect it is far from sure that contemporary financial innovations display the same features and contribution to welfare than technical and organizational ones: some of them are more predatory than growth enhancing. De facto the American economy should not be any more the benchmark in terms of financial organization: since the early 80 s, the successive financial 
innovations have not benefited so much to manufacturing and service firms and households but they have been self- serving for financiers themselves. The explosion of the assets of brokers and dealers is impressive compared with the stability of the related trend for commercial banks. This induces unsustainable leverage ratios that lead to the crisis (Figure 1).

Figure 1: Innovations that have triggered an explosion of leverage effects within the financial system itself

This is an important message for emerging economies: dominated in terms of financial innovations they can avoid the direct costs of failed instruments and conceive a financial system adequate to their growth strategy and social objectives: they are not bound to mimic developed world configurations. In a sense it is an updating and an extension from manufacturing to finance of the old finding by Alexander Gershenkron (1962): backwardness can be good if it allows skipping an inefficient stage, painfully explored by leading powers. The emerging countries can even leap through.

\section{A SPECTRAL ANALYSIS OF THE WORLD ECONOMY}

Three other lessons point out the changes that emerging economies imply in the restructuring of the international relations. Initially rather marginal, they might become, in the long run, key actors in the international division of labor and world regime.

\section{III.1 - A reassessment of globalization: nor disconnection, neither leading role of emerging countries}

Globalization is a catch word that tries to capture a wide range of transformations operating since the early 80s. External trade grows faster than domestic activity, most goods tend to imply a worldwide value chain, the amount of financial flows largely exceed that of foreign direct investment, the mobility of transnational firms challenge the regulatory and fiscal power of Nation-States, some American norms tend to become world standards, and last but not least, huge populations are now involved in capitalist relations and competition. Furthermore with the risks over financial stability and the uncertainty about climate change, new global public goods are emerging.

Let us limit ourselves to the teachings of the years 2008-2011 about a limited component of globalization, i.e. the strength of multiple, new and complex interdependencies between nations, sectors and domains. First of all, the United States still are, for best or worse, the center of impulsion for economic and geopolitical matters: the subprime collapse was home grown, even if the inflow of foreign savings have exacerbated the domestic unbalances. Second, the thesis of a possible disconnection from the vagaries of the world economy has been invalidated: The European Union has been first a shield and then a liability due to the absence of a clear leadership and strategy. Even the very dynamic East Asia region was hit by the free fall of world trade from October 2008 to March 2009 and of course North Korea is not an especially attractive example for a successful autonomy from an alleged chaotic capitalist system. Impressed by the dynamism of China, India and Brazil some analysts had anticipated that this club of emerging economies could stabilize the world economy and counterbalance the adverse impact generated by the American difficult recovery and probable slowing down during the present decade. The third teaching is that this has not been the case, given the respective size of the economies of mature and emerging countries and their different geopolitical objectives. History suggests that the shift from one center of gravity 
of capitalism to another is a painful and long process, possibly accelerated by major crises and wars.

\section{III.2 - A strong differentiation of national institutional configurations, faraway from a convergence towards a canonical brand of capitalism}

Another meaning of globalization, yesterday explicit under the banner of the Washington Consensus and now often implicit, points out the desirable/necessary convergence towards a canonical brand of economic system, usually that of finance led capitalism: light touch regulation, flexible labor markets, workfare and limited public spending and low taxation. The last years have shown that financialization has reached its limit in US and UK and that alternative models exhibit a clear resilience. Observing the reactions of governments to the same world crisis delivers an interesting, even if provisional, taxonomy of contrasted institutional configurations (Boyer, 2011).

asically the pattern of evolution of the world economy is not the outcome of a single brand of capitalism since it results from the interaction of finance dominated capitalisms - they provide international intermediation and liquidity and are consumers of last resort - industrialist continental economies - they deliver the basic manufactured consumption goods and finance the public and external deficit of the first group - and rentier regimes that prosper exporting primary commodities when both others configurations are promoting a rapid growth (figure 2).

Figure 2: The coexistence and partial compatibility of contrasted configurations

The other modes of development are articulated with the previous three poles that set the pace of the world economy: some economies are financially dependent from foreign capital inflow, others rely upon innovation and export to propel their growth, whereas some societies experience hybrid forms where the insertion into the international relations is disarticulating the coherence of domestic economic and social basic institutions. Finally some rare societies stay rather isolated from the rest of the world, inward looking or poorly integrated, they are not so affected by the vagaries of the world economy.

Far from implying similar macroeconomic patterns, these seven regimes display specific features due to their economic specialization and institutional and political institutions. Consequently they are largely complementary: financial dominated capitalism requires financially dependent ones, industrialist regimes have to buy the natural resources provided by rentier regimes and they prosper with the booms of finance led capitalism. The US and China still have quite complementary profiles: the American external deficit is partially financed by the flow of saving from China, the overconsumption on one side limits the over accumulation on the other side. In a sense the competition among these groups is limited, but more acute within each of them. For instance, Germany, Japan and South Korea do compete in order to stay at the technological frontier and oil producing countries may display different strategies in order to capture the world market, but nobody imagines that Saudi Arabia competes with Germany and until now the continental economies have not reached the technological frontier that is still dominated by old industrialist countries that have not been seduced by the mirage of finance.

One major implication of this taxonomy has to be stressed: emerging economies belong to different categories, since Russia is a typical rentier regime, India is an emblematic continental economy and some former emerging countries, Argentina in the 60s, Mexico in the 70s have ended exploring the difficult path of an hybrid configuration, finally disarticulated by an inadequate insertion into the world economy. The international financial crises display therefore 
different forms and the reforms to prevent them should be adapted to their prevailing domestic regime and/or its strategic reorientation. This complexity is at odds with the "the same size for all strategy", the international organizations used to be fond of, and it calls for a new research agenda in institutional and historical macroeconomics.

\section{III.3 - The volatility of international financial flows has increased with the radical uncertainty associated with the 2009 crisis and it puts at risk most national development strategies.}

The bursting out of the American financial crisis has opened a rather uncertain period since the previous shared expectations have been eroded or even destroyed: how likely is a return to the past American credit led growth? Can emerging economies propel the world system out of the risk of depression? Will Eurozone governments be able to overcome the public debt creeping crisis and to redesign the institutional architecture of the European Union? Some recent advances in economic theory point out that these radical uncertainties hinder the very possibility of a rapid and sustainable recovery (Bloom, 2009). Under this respect, the emerging countries alternatively benefit and then suffer from the brutal shifts in the expectations of leading international financiers: since September 2008 inflows and outflows have alternated with an increasing frequency (Figure 3).

Figure 3 - Massive inflows and sudden stops: the volatility of international capital has increased

This pattern is quite preoccupying since this instability has been in the past the source of major financial and economic crises for the so called emerging economies (Krugman ,1979, 1999). Furthermore since exchange rates are now governed by financial flows and not at all commercial trade balances, they experience unprecedented and large swings (Figure4).

Figure 4: The swing in exchange rates destabilizes the domestic development modes.

These two features might have a strong impact upon the resilience and long term viability of most emerging economies growth regimes. The structurally financially dependent ones would be the more affected by a muddling through scenario whereby national governments and international organizations would be unable or unwilling to agree upon new rules for the world financial system (table 2). Similarly rentier economies could also alternatively gain and then loose from the vagaries of natural resources prices and exchange rates wide fluctuations. By contrast, continental economies are in better position to control their insertion into international relations and to monitor their domestic economic activity. Consequently if the recent evolutions were to prolong themselves, the heterogeneity of emerging economies would be exacerbated and lead to possibly diverging trajectories. Conversely, a stabilization of exchange rates and a moderation of international capital flows would restore a form of complementarity between the various growth regimes; this would define a rather favorable scenario for emerging economies.

Table 2: The coevolution of national regimes and the international system

\section{THE RELATIONS BETWEEN LATIN AMERICA AND ASIA: A NEW EMERGING PATTERN}

The Asian financial crises have shown a quite different pattern compared with the ones observed in Latin America, even if both have learnt how to deal with them. Nevertheless 
the present crisis could well initiate tipping point in the transformation of the world economy, both at the regional level and within each region.

\section{IV.1 - A source of diverging national trajectories: Mexico still articulated with the United States, Brazil and Argentina more and more linked to China and Asia.}

In the early days of globalization, many analysts used to think that geographical proximity and the belonging to the same region would imply a progressive convergence towards a common socio-economic regime. This illusion has been especially costly for the European Union: the adhesion to the Euro has deepened the differentiation of productive systems with diverging competitiveness between northern and southern member States. The German model which was the implicit benchmark has not been emulated by others and Nordic countries have followed their own way, whereas so called Mediterranean capitalisms have remained largely unchanged (Amable, 2003).

Mutatis mutandis, an equivalent process seems to have taken place between Mexico on one side, Latin America on the other side. The first economy is so closely linked to the evolution of the United States by trade, foreign investment, migration and income transfers that the recession after 2008 has been far more acute than in Brazil or Argentina. This not an accident since it expresses also the very few policy instruments available for the Mexican government in terms of interest and exchange rate policy (Romero, 2012; Esquivel, 2012). By contrast one of the novelty exhibited by the period 2008-2012 is that China and more generally Asia have become the first or at least a major trade partner for many Latin American economies. Furthermore, they usually have developed some degrees of freedom in their economic policies that allowed them to mitigate the fall of world trade (Bruno et alii, 2011). In other words, the fact that the Mexican GDP is strictly correlated with the North American one, but that the Brazilian GDP becomes more and more synchronized with Chinese industrial output means that a major bifurcation has taken place.

It is also a partial explanation for the difference in the geopolitical strategies of the two governments concerning the processes of regional integration and reconstruction of the international relations. But of course the difference in terms of integration into the world economy is not the only discriminating factor since quite contrasted socio-economic compromises and institutional architectures are observed in each economy when one compares not only Mexico and Brazil but also Argentina (Biztberg and Theret, 2012) and Chile (Miotti et alii. , 2012).

\section{IV.2 - A possible future South/South complementarity: Latin America and Asia}

Another bifurcation seems to be confirmed by the last decade compared with the previous one and the crisis might well speed up a major change in the division of labor at the world level. The progressive macroeconomic stabilization reached by most Latin American countries in the 90s had raised the hope that they could get a faster and more inclusive growth by a process of reindustrialization. This has been partially successful within the post currency board strategy in Argentina and it is a permanent concern for Brazilian authorities, whereas Chile has added value to its primary products via innovations related to this specialization. Nevertheless the dynamism of the demand of primary products from China and to a minor extent from US has triggered a significant appraisal of the terms of trade in favor of Latin America.

In spite of their projects of conversion of the revenue derived from their exports into productive investment in the manufacturing sector and RD expenditures, in Latin America the international specialization has evolved towards a greater reliance upon primary products export 
led growth not only for Chile and Argentina, but also for the most industrialized economy of the region, i.e. Brazil . The counterpart has been a strengthening of specialization of Asia and typically China, in the manufacturing of most manufactured consumption goods for the world market (Figure5). By the way the other impact is rather detrimental for the manufacturing sector of many economies that are unable reach the technological frontier. Even their informal sector is living out of the import of Chinese goods and domestic producers are replaced by traders with adverse impact upon value creation and income distribution (Alba, 2011). Some analysts imagine that this polarization could be the premise of a new South/South division of labor (Hugon and Pereira, 2011). But such a de facto complementarity could define a strong constraint upon domestic strategies unless it is codified by long term international agreements governing the evolution of the terms of trade between manufactured products and primary resources. The relative decline of the US and EU could consolidate this emerging and quite new configuration of the world economy.

Figure 5 - Industrialization in Asia, specialization in primary commodities in Latin America

\section{EMERGING PRINCIPLES FOR ECONOMIC POLICIES}

If correct, the previous analysis has definite consequences for economic policies and reforms that could prevent the repetition of contemporary crises. On the one hand, the Washington Consensus has globally failed in most of its recommendations, especially concerning un-discriminated financial opening and development. On the other hand, the cleat differentiation of various socio-economic regimes and national trajectories makes "the same policy for all" quite problematic. Nevertheless, some general orientations can be proposed.

\section{V.1 - A difficult trade-off: trade and financial opening may foster growth but it increases volatility and risks of instability}

Most economists agree that Asia has been the main beneficiary of globalization: a fast catching up has fostered growth and it has reduced poverty, however at the cost of wider inequalities. Asian economies now have a clear specialization within the international division of labor and they have improved the standards of living of a significant fraction of their population. Nevertheless the other face of the coin is quite preoccupying: at odds with previous inward looking growth strategies, such a wide opening makes the domestic economy more vulnerable to external shocks and possible disruption of the world economy.

A comparative analysis of East Asian economies shows that the degree of trade openness and internal and external financial liberalization is a key discriminating factor of their institutional configurations (Harada and Tohyama, 2011). Still more interestingly, the related index is closely related to macroeconomic volatility during the most recent period: Indonesia, the Philippines and China seem the less vulnerable and at the other extreme Hong Kong and Singapore are highly sensitive to the instability of the international economy (Figure6). Of course larger countries have access to diversification and they enjoy a larger domestic market, but the degree of liberalization does contribute to macroeconomic, instability even in highly sophisticated and innovative economies.

Figure 6: The adverse impact of internationalization and financial liberalization upon macroeconomic stability 
This is trade-off between growth and macroeconomic stability should be explicitly taken into account and discussed by policy makers.

\section{V.2 - Some control over the exchange rate is possible and it may contribute to macroeconomic stability.}

The previous finding provide an argument for searching for methods that would preserve most of the benefits of the international division of labor, while improving the resilience of the economy facing recurring external shocks and world crises. China has probably been the most successful in this strategy: capital inflows are controlled by public authorities in order to keep an exchange rate adequate with the national growth strategy. The conventional theory anticipates significant losses of welfare, but they are overwhelmed by the gains in terms of dynamic economic efficiency (Boyer, 2011). A long time ago, the Chilean governments have had to introduce a genuine mechanism in order to sterilize capital inflows that would destabilize the economy (Ffrench-Davis 2003). Argentina shows that a competitive exchange rate can be monitored by the government at least in the medium term, if not in the long run, at the benefit of growth, job creation and poverty reduction (Boyer and Neffa, 2007).

Therefore more experts are now convinced that capital controls are not the absolute evil that should be prevented, since they might be helpful given the context of the huge speculative inflows and outflows and the inability of markets to deliver exchange rates compatible with long term competitiveness of each country. Last but not least, the Swiss central bank has recently decided to go against the market in order to defend the stability of the domestic economy. This means that the issue of capital control is no more a pure matter of ideological and political preference but it is the outcome of a pragmatic approach to economic stabilization.

\section{V.3 - Since private credit is strongly pro-cyclical, a public investment bank helps in promoting long term growth}

The inability of direct finance to cope with radical uncertainty and the fact that banks act pro-cyclically in their assessment of risk and give easily credit in boom periods and cut it in bad times, are two of the main causes of recurring business cycle and of rare but devastating systemic financial collapses when potentially far reaching innovations, either productive or financial, raise excessive profit expectations (Boyer et alii., 2004). Emerging economies suffer from the same weaknesses, the more so if they have fully opened and liberalized their financial system. Of course adequate regulations promoting a counter-cyclical move of prudential ratios, bank reserves and possibly taxation in order to build a stabilization fund, are welcome.

Nevertheless, the specificity of emerging countries calls for the implementation and constant upgrading of a major public bank. Its role: financing investment in infrastructures and risky innovations that private banks are unwilling to finance given their objectives in terms of shareholder value. The benefits are twofold: on one side, this public bank contributes to capital formation and long term growth, with a possible crowding in for private banks, and on the other side, during recessions or systemic crises, they can exert a strong impact in mitigating the decline of investment and still contributing to the future of potential growth. The most extended experience of such a policy belongs to Brazil with its development bank BNDES but quite few other Latin American have been able to use efficiently such a public bank (Jennifer,2010) . Another impressive example relates to the control of bank credit by Chinese authorities: it allowed a quick expansion of credit in order to foster investment in infrastructures and thus counter the 
depression of world trade, but at the risk of exacerbating the over accumulation and the disfunctionality of its investment led growth regime.

Finally the successful countries exhibit a common feature since they display a complementarity between public interventions and private initiatives: they are mixed economies, i.e. an updated form of the configurations analyzed in the 60s by Andrew Shonfield. In the contemporary world, the public control over credit might well be as important as the management of taxes and public spending. .

\section{FINANCE FOR DEVELOPMENT: IN SEARCH FOR ALTERNATIVE PARADIGMS}

Two last lessons have to be extracted from the complexity of the present painful processes that govern possible ways out of the crisis, one relates to the direction of financial innovations and the second points out the need for a new overarching vision and theory of development.

\section{VI.1 - The last two decades financial innovations have failed to foster development}

In retrospect, the promises of the supporters of financial globalization, who thought that this would be one of the drivers of development and would lead to convergence towards a canonical model, have been falsified. Yes the opening to world trade and domestic institutional reforms have generated a new wave of industrialization and development, but the globalization of finance has been more a hindrance than a trump. The frequency of crises has increased, macroeconomic volatility destabilizes most socio-economic regimes, and some countries have experienced a major social and political turmoil after a financial collapse, yesterday Argentina, today Iceland and Greece.

But the more impressive failure concerns the perverse allocation of capital at the world level. The objective of financial deregulation was to promote an efficient and rational allocation of capital and competences: the saving of rich developed countries would flow to poorest underdeveloped ones, finance their investment and speed up their growth. Unfortunately short term financial speculation has taken the lead at the detriment of productive investment. Furthermore, the governments of emerging countries had to emit debts in dollars, and not in their own currency, and this "original sin" has induced an impressive concentration of financial intermediation in Wall Street and the City. The outcome is a paradoxical allocation of resources where low income countries finally finance the consumption and real estate speculation of very rich economies (Figure7). Lastly domestic financial regulations have been reduced but no equivalent rules have been implemented at the international level: such a complex unregulated system was increasing the probability of financial crises and it was not resilient enough to cope with the consequences of the subprime collapse.

Figure 7: Poor countries are financing the consumption and even speculation in the US

The issue at stake is therefore clear: how to promote the reconciliation of financial innovation at a more local level with development? 


\section{VI.2 - A clear need for new development theories}

In turn a new development requires an aggiornamento of the economic theory that failed to provide any understanding of the events that led to the 2001 Argentina braking down, the September 2008 melting down of the American financial system or the transformation of Iceland into an hedge fund. Symmetrically, the trajectories of China since 1978, the surprising recovery of Argentina after 2003, the resilience of Brazil and India seem to violate most of the recommendations of conventional economic theory.

It is time to design a research agenda that would aggregate the best intuitions and hypotheses of alternative approaches, test them against the evidence derived from long run historical analyses and systematic international comparisons. The outcome should be flexible enough to cope with the coexistence of a significant variety of socioeconomic regimes and then allow the analysis of their interactions.

\section{REFERENCES}

Alab VEGA Carlos (2011), "La mondialisation par le bas et ses formes de régulation politique", Revue Tiers monde, $\mathrm{N}^{\circ} 208$

Amable Bruno (2003), The Diversity of Modern Capitalisms, Oxford, Oxford University Press.

Amable Bruno, ERnst Ekkehart., PAlombarini Stefano (2005), "How do financial markets affect industrial relations: an institutional complementarity approach", Socio-Economic Review, vol.3, n² 2 , p. 311-330. .

AOKI Masahiko (2002), Toward a comparative institutional analysis, Cambridge (MA): MIT Press.

Bernanke Ben, Mark Gertler and Simon Gilchrist (1999), "The Financial Accelerator in a Quantitative Business Cycle Framework", in TAYLOR and WOODFORD eds., Handbook of Macroeconomics, Amsterdam.

BITZBERG Ilan, Bruno THERET (2012 ) « Pourquoi le Brésil, et non l'Argentine et encore moins le Mexique, peut-il être considéré comme un pays (re)émergent? " Revue de la Régulation, $\mathrm{n}^{\circ} 11$.)

BLOOM Nicholas (2009), “The impact of Uncertainty Shocks”, Econometrica, vol. 77, n 3, p. 623685.

Borio Claudio (2010), Ten Propositions about Liquidity Crises, CESifo Economic Studies, Vol. 56 (1), p. 70-95.

BOUCHAUd Jean-Philippe (2008), «Economics needs a scientific revolution », Physics.so-ph, 29 Octobre

BOYER Robert (2000), "Is a finance-led growth regime a viable alternative to Fordism? A preliminary analysis", Economy and Society, Vol. 29, n 1, February, p. 111-145.

BOYER Robert (2008), History Repeating for Economists. An anticipated Financial Crisis, Prisme $\mathrm{n}^{\circ} 13$, November, Cournot Centre for Economic Research, Paris. http://www.centrecournot.org/prismepdf/Prisme 13 EN.pdf

BOYER Robert (2011), Les financiers détruiront-ils le capitalisme? Economica, Paris

BOYER Robert (2011), "China in historical and institutional perspective”, in Boyer Robert, Hiroyasu Uemura and Akinori Isogai (eds) Diversity and transformations of Asian Capitalisms, Routledge, London, p. 243-263-

Boyer Robert, Mario DeHOve and Dominique Plihon (2004), Les crises financières, Rapport du Conseil d'analyse Economique, $\mathrm{n}^{\circ} 50$, La documentation française, Paris.

BOYER Robert, NeFFA Julio (2007) "¿Se abre una nueva era para la economía Argentina? Un análisis de las transformaciones estructurales después de la crisis de la convertibilidad". Boyer, 
Robert, Neffa, Julio C (eds), Salida de crisis y estrategias alternativas de desarrollo. La experiencia argentina. Buenos Aires: MIÑO Y DAVILA,

Bruno Miguel, Joseph HALEVI, Jaime MARQues Pereira (2011) « Les défis de l'influence de la Chine sur le développement du Brésil »Revue Tiers Monde, n²06, p.83-102.

CAPrio Gerard Jr., DemirgüÇ-Kunt Asli and Edward J. KANE (2010), "The 2007 Meltdown in Structured Securitization: Searching for Lessons not Scapegoats", The World Bank Research Observer, Vol. 25, n 1, February, p. 125-155.

CROTTY James (2009), "Structural causes of the global financial crisis: a critical assessment of the 'new financial architecture", Cambridge Journal of Economics, Vol. 33, n 4, July, p. 563-580.

Davis E.P. (1992), Debt, Financial Fragility and Systemic Risk", Oxford University Press, Oxford.

DemirgüÇ-Kunt Asli and Luis SERVÉN (2010), “Are all the Sacred Cows Dead? Implications of the Financial Crisis for Macro- and Financial Policies", The World Bank Research Observer, Vol. 25, n 1, February, p. 91-124.

Dosi Giovanni, FAgiolo Giorgio and Andrea Roventini (2010), Schumpeter meeting Keynes: A policy (friendly model of endogenous growth and business cycles, Journal of Economic Dynamics and Control, doi:10.1016/j.jedc.2010.06.018.

ESQUIVEL Gerardo (2012), las limitantes del modelo económico de Mexico" conferencia internacional" America Latina ante los distintos escenarios de salida de la crisis global" Colegio de Mexico , 28-29 febrero

FFRENCH-DAVIS Ricardo (2003)" The capital account and real macro-economy" University of Chile

FASTEN Erik R. and Eloïse ORSEAU (2010), Sudden Death or Glorious Convalescence: Risk Transfers, Cross-country Spillovers and Sovereign Defaults", Mimeograph European Central Bank, Frankfurt am Main, June $11^{\text {th }}$.

FERRER Aldo (2011) "Raul Prebisch y el dilema del desarrollo el mundo global", Revista de la Cepal, n¹001, Agosto, p7-15

Garber Peter M. (2000), Famous First Bubbles: The Fundamental of Early Mania, Cambridge: MIT Press.

GEANAKOPOLOS John (2010), Solving the Present Crisis and Managing the Leverage Cycle, Cowles Foundation Discussion Paper, $n^{\circ}$ 1751, Yale University, New Haven Connecticut, January.

Gershenkron Alexander (1962), Economic Backwardness in Historical Perspective , Cambridge University Press, Cambridge.

Goodhart Charles A.E., Osorio Carolina, and Dimitrios Tsomocoss (2010), "Analysis of Monetary Policy and Financial Stability: A new Paradigm", Paper prepared for presentation at the CESifo Economic Conference on What's Wrong with Modern Macroeconomics?, Munich, November 6-7 ${ }^{\text {th }}$.

GourINCHA Pierre-Olivier (2010), U.S. Monetary Policy, 'Imbalances' and the Financial Crisis, Remarks prepared for the Financial Inquiry Commission Forum, Washington DC, February 26-27.

Greenberger Michael (2010), The Role of Derivatives in the Financial Crisis: Testimony, Financial Crisis Inquiry Commission Hearing Dirksen Senate Office Building, Washington DC, June 30.

Haldane Andrew G. (2010), "The contribution of the Financial Sector. Miracle or Mirage?, Mimeograph Bank of England, in Andrew Haldane, Simon Brennan and Vasileios MADOUROS, The Future of Finance: The LSE Report", London school of Economics, July.

HARADA Yuji, Hironori TOHYAMA (2012), “Asian capitalisms: institutional configurations and firm heterogeneity, in Boyer Robert, Hiroyasu Uemura and Akinori Isogai (eds) Diversity and transformations of Asian Capitalisms, Routledge, London, p. 243-263-

HUGON Philippe, MARQUES PEREIRA Jaime (2011) «Économie politique tricontinentale : les nouveaux paradigmes suds-suds $\Perp$, Revue Tiers monde , $\mathrm{n}^{\circ} 21$ 
JENNIFER Herman (2010), "Development banks in the financial-liberalization era; The case of BNDES in Brazil", Cepal Review, n 100 , p180-201.

Jenkinson Nigel, Penalver Adrian, and Nicholas VAuse (2008), Financial innovation: what have we learnt?, Reserve Bank of Australian Conference on Lessons from the financial turnmoil of 2007 and 2008, Sydney 14-15 July.

KINDLEBERGER Charles P. (1978), Manias, panics and crashes, Basics Books, New York.

KING Mervyn (2009), "Finance: a Return from Risk", Speech to the Worshipful Company of International Bankers, at Mansion House, March $17^{\text {th }}$.

KNIGHT Frank Hynemann (1921), Risk, Uncertainty and Profit, Harper \& Row, réédition (1965).

KRugman Paul (1979), "A Model of Balance of Payments Crises", Journal of Money, Credit, and Banking, v. 11, n'. 3, pp. 311-25, August.

KRUGMAN Paul (1999), "Balance sheets, the transfer problem and financial crises", in International finance and financial crises: Essays in honor of Robert P. Flood, Jr., cd. By Peter IsARD, RAZIN Assaf and Rose Andrew K. (Boston: Kluwer Academic: Washington: International Monetary Fund).

Krugman Paul (2001), "Crises: The Next Generation?”, Razin conference, Tel Aviv University, March 25-6. (http://econ.tau.ac.il/research/sapir/Krugman.pdf)

Krugman Paul (2009), "How did Economists Get It So Wrong?", The New York Times, September $2^{\text {nd }}$.

LO Andrew W. (2009), "Regulatory reform in the wake of the financial crisis of 2007-2008", Journal of Financial Economic Policy, vol. 1, N 1, p. 4-43.

MaCKenZIE Donald and Yuval Millo (2003), "Constructing a market, performing theory: the historical sociology of a financial derivatives exchange", American Journal of Sociology, 109: 10745.

MACKENZIE Ronald (2008), An engine not a camera; How financial models shape markets, MIT press, Cambridge

McDonough Terrence, Michael ReICH and David M. Kotz (2010), Contemporary Capitalism and Its Crises. Social structure of accumulation theory for the $21^{1 t}$ century, Cambridge University Press, New York.

MiNSKY Hyman (1982a), Can it happen again? Essays on Instability and Finance

MiotTi Luis Egidio, Carlos Quenan, Edgardo Torija Zane (2012), «Continuités et ruptures dans l'accumulation et la régulation en Amérique Latine dans les années 2000 : Argentine, Brésil et Chili », Revue de l a Régulation, n¹1, avril.

MORENO-BRID Juan carlos, Jaime Ros (2010) » LA DIMENSION INTERNACIONAL DE LA ECONOMIA MEXICANA" EN FICKER SANDRA KUNTZ COORDINATORA HistORIA ECONOMICA GENERAL De Mexico, El colegio de Mexico, Mexico

OrLeAn André (1989), "Mimetic Contagion and Speculative Bubbles", Theory and Decision, Vol. 27, no 1-2, July-September, p. 63-92.

PALMA José Gabriel (2009), "The revenge of the market on the rentiers / Why neo-liberal reports of the end of history turned out to be premature", Cambridge Journal of Economics, Vol. 33, n 4 , July, p. 829-869.

ReInhart Carmen and Kenneth RogofF (2009), This Time is Different. Eight Centuries of Financial Folly, Princeton University Press, Princeton.

Romero José (2012), El modelo economico mexicano ante las nuevas condiciones internacionales conferencia internacional" America Latina ante los distintos escenarios de salida de la crisis global" Colegio de Mexico, 28-29 febrero .

SORNETTE Didier (2003), Why Stock Markets Crash. Critical Events in Complex Financial Systems, Princeton, NJ, Princeton University Press.

Stiglitz Jopseph E. and Bruce Greenwald (2003), Towards a New Paradigm in Monetary Economics, Cambridge University Press, Cambridge Ma.

Vogel Harold (2010), Financial Market.Bubbles and Crashes, Cambridge University Press, Cambridge 
Table1: The contrast between the economies that had already experienced sudden stops and the others

Proportion of credit in foreign currencies related total assets (\%)

\section{Pays émergents : prêts en devises}

\begin{tabular}{l|l} 
& (en \% d \\
\hline Bulgarie & 66,9 \\
Croatie & 62,0 \\
Rep. Tchèque & 13,6 \\
Estonie & 85,3 \\
Hongrie & 65,7 \\
Lettonie & 89,3 \\
Lituanie & 64,0 \\
Pologne & 32,6 \\
Roumanie & 55,5 \\
Russie & 15,3 \\
Turquie & 28,9 \\
Ukraine & 59,5 \\
\hline
\end{tabular}

\begin{tabular}{l|c}
\hline Inde & 1,4 \\
Indonésie & 19,8 \\
Corée & 8,5 \\
Vietnam & 21,2 \\
Argentine & 15,8 \\
Brésil & 2,0 \\
Colombie & 6,3 \\
Mexique & 11,6 \\
Pérou & 57,5 \\
Venezuela & $<0,5$ \\
\hline
\end{tabular}

Sources : FMI, NATIXIS 
Figure 1: Innovations that have triggered an explosion of leverage effects within the financial system itself bur not for economic activity

Growth of Assets of Four Sectors in the United States (March $1954=1$ ) (Log scale) (source: Federal Reserve, Flow of Funds, 1954-2009)

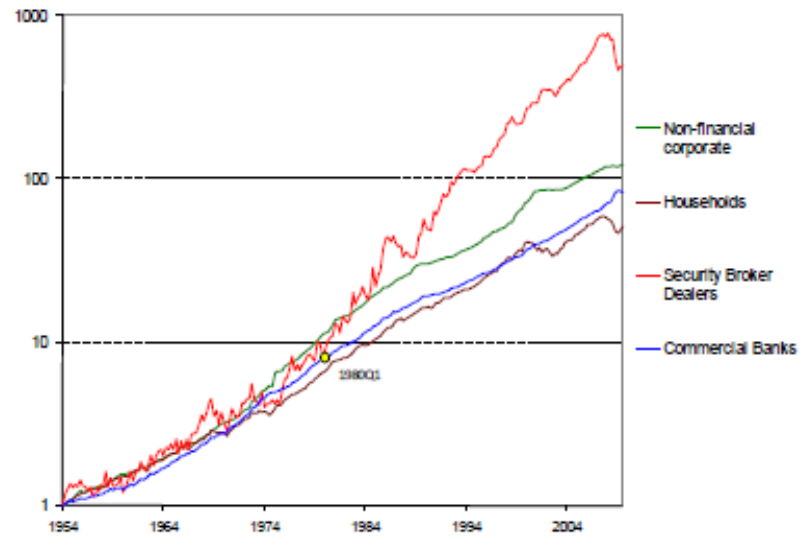

Source: Tobias Adrian, and Hyun Song Shin (2010), The Changing Nature of Financial Intermediation and the Financial Crisis of 2007-2008, Staff Report $n^{\circ} 439$, Federal Reserve Bank of New York, March-April., p. 6-10 et 11.

Figure 2: The coexistence and partial compatibility of contrasted configurations

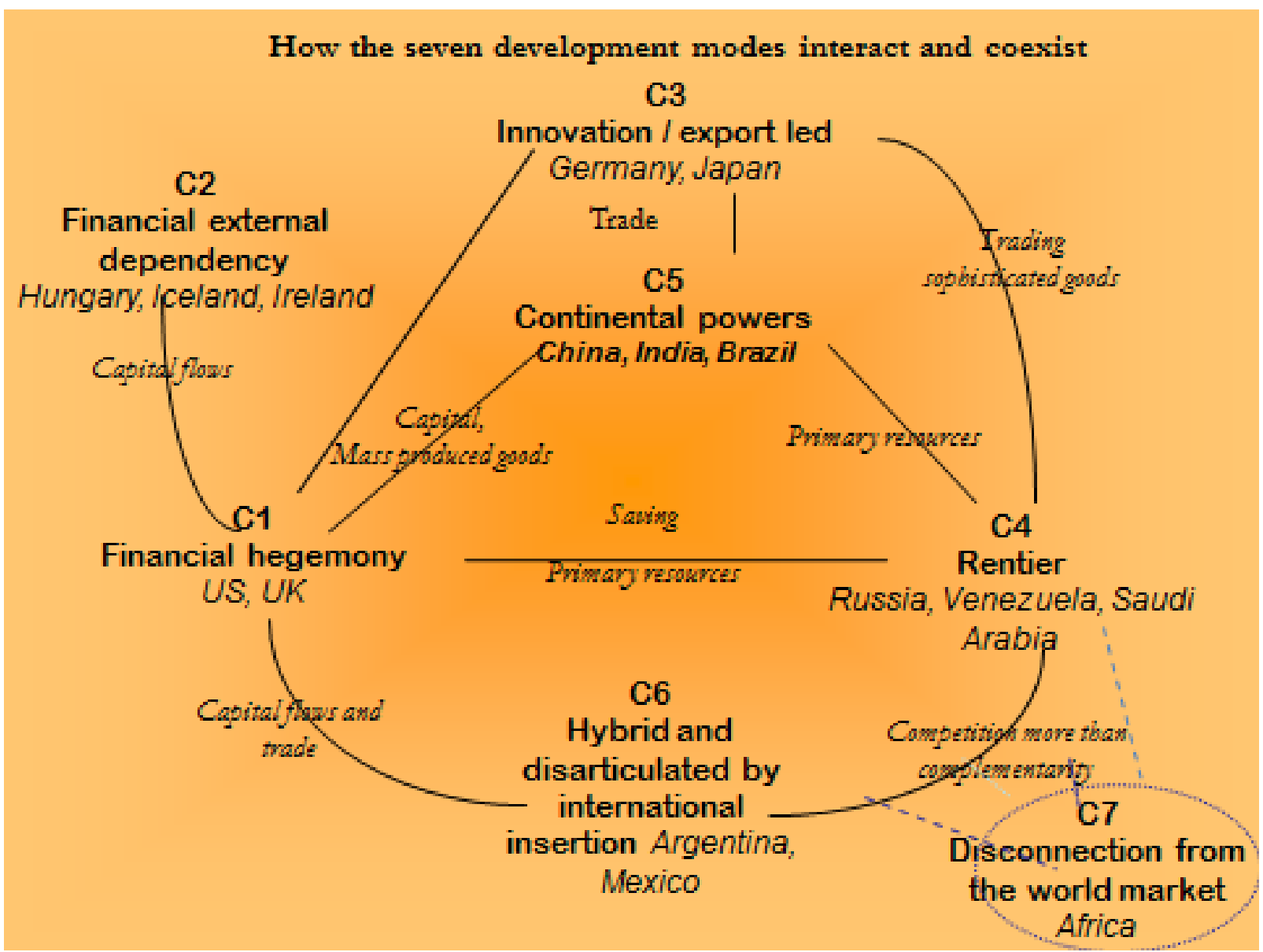


Figure 3: Massive inflows and sudden stops: the volatility of international capital has increased (Monthly flows of capital towards emerging countries, Russia and China excluded)

.... This triggers brusque reversals in capital flows towards emerging economies

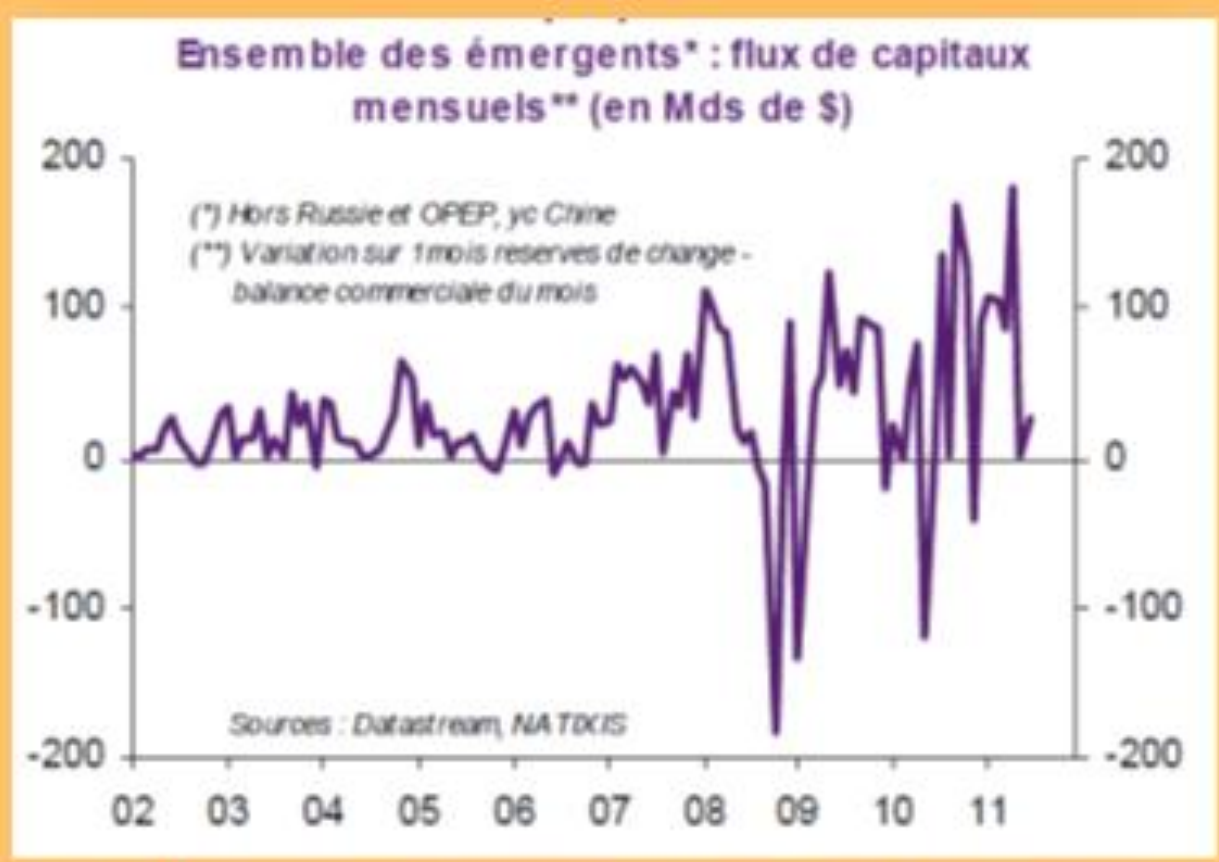

Source : Artus Patrick (2011), "Pourquoi les capitaux sortent-ils des pays émergents quand l'aversion pour le risque est forte?", Flasb Economie, 755, 10 Octobre, p. 2.

Figure 4: The swing in exchange rates destabilizes the domestic development modes.

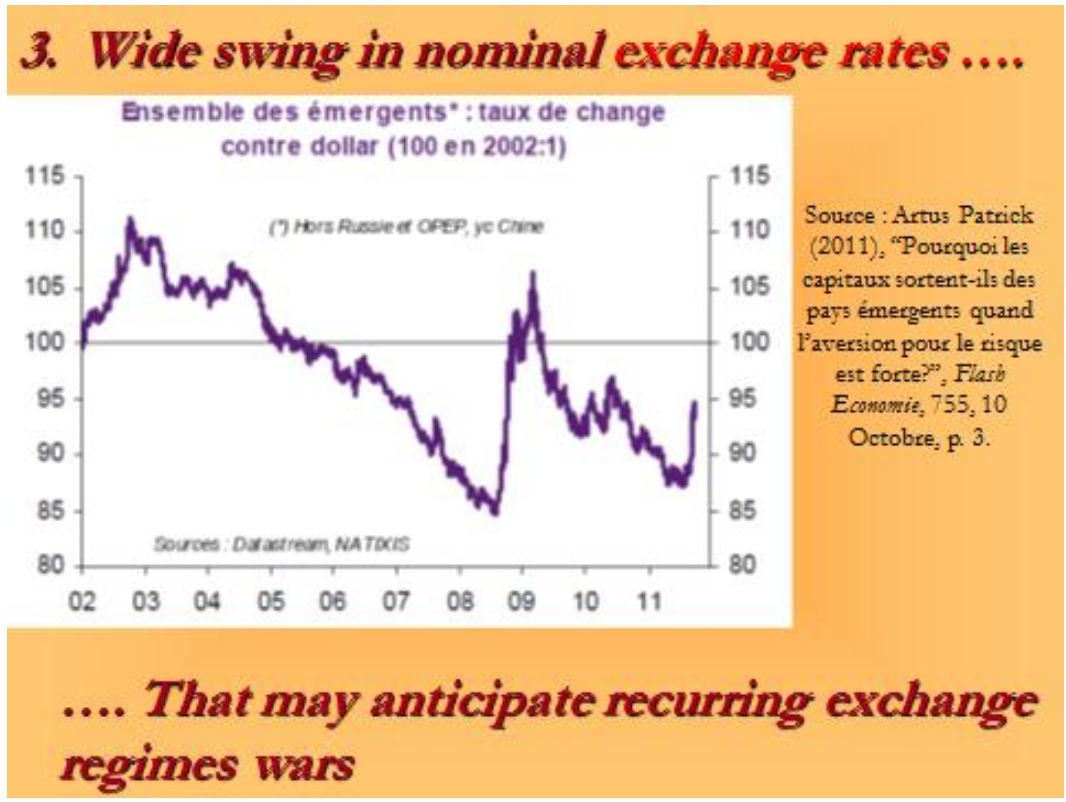


Table 2

The co-evolution of national regimes and the international system (1)

\begin{tabular}{|l|c|c|c|}
\hline Worlional Regime & $\begin{array}{c}\text { Finance led and } \\
\text { dominant }\end{array}$ & $\begin{array}{c}\text { Financial } \\
\text { dependant }\end{array}$ & $\begin{array}{c}\text { Innovation / } \\
\text { exportation }\end{array}$ \\
\hline 1. Muddling through & $\begin{array}{c}\text { From one crisis to } \\
\text { another }\end{array}$ & Phasing out & Heavily penalized \\
\hline $\begin{array}{l}\text { 2. Collapse and } \\
\text { balkanization }\end{array}$ & $\begin{array}{c}\text { Collapse but possible } \\
\text { restructuring at the } \\
\text { national level }\end{array}$ & $\begin{array}{c}\text { Incentives to } \\
\text { financial } \\
\text { protectionism }\end{array}$ & $\begin{array}{c}\text { Possible integration } \\
\text { into domestic led } \\
\text { growth at the } \\
\text { regional level }\end{array}$ \\
\hline $\begin{array}{l}\text { 3. A new Bretton } \\
\text { Woods }\end{array}$ & $\begin{array}{c}\text { Transition towards } \\
\text { another regime in } \\
\text { response to the } \\
\text { down grading of the } \\
\text { dollar }\end{array}$ & $\begin{array}{c}\text { Exploration of } \\
\text { alternatives, export } \\
\text { or consumption led } \\
\text { regimes }\end{array}$ & $\begin{array}{c}\text { The possible major } \\
\text { beneficiary of the } \\
\text { stabilization of } \\
\text { international } \\
\text { relations }\end{array}$ \\
\hline
\end{tabular}

La coévolution des régimes nationaux et du système international (2)

\begin{tabular}{|c|c|c|c|}
\hline World Scenario & Rentier & $\begin{array}{l}\text { Continental } \\
\text { Economy }\end{array}$ & $\begin{array}{c}\text { Hybrid/ } \\
\text { Disarticulation }\end{array}$ \\
\hline 1. Muddling through & $\begin{array}{l}\text { Suffers from } \\
\text { higher volatility }\end{array}$ & $\begin{array}{l}\text { More centripetal } \\
\text { forces }\end{array}$ & $\begin{array}{l}\text { More disintegrating } \\
\text { forces }\end{array}$ \\
\hline $\begin{array}{l}\text { 2. Collapse and } \\
\text { Balkanization }\end{array}$ & $\begin{array}{l}\text { A general slow } \\
\text { down reduces } \\
\text { income and wealth }\end{array}$ & $\begin{array}{l}\text { Still more incentives } \\
\text { to inward looking } \\
\text { growth strategy }\end{array}$ & $\begin{array}{c}\text { Possible bifurcation } \\
\text { towards a demand led } \\
\text { regime }\end{array}$ \\
\hline $\begin{array}{l}\text { 3. A New Bretton } \\
\text { Woods }\end{array}$ & $\begin{array}{l}\text { Better trade off } \\
\text { between long term } \\
\text { growth and } \\
\text { stability }\end{array}$ & $\begin{array}{l}\text { A recognition of } \\
\text { their role in } \\
\text { international } \\
\text { institutions }\end{array}$ & $\begin{array}{l}\text { Favors a return to a } \\
\text { coherence between } \\
\text { domestic institutions } \\
\text { and adhesion to the } \\
\text { international regime... } \\
\text {...but it is up to } \\
\text { specialization and } \\
\text { political options } \\
\text { Mexico vs Argentina) }\end{array}$ \\
\hline
\end{tabular}


Figure 5: Industrialization in Asia, specialization in primary commodities in Latin America

A deepening of national specialization: a possible complementarity between LatinAmerica and China?

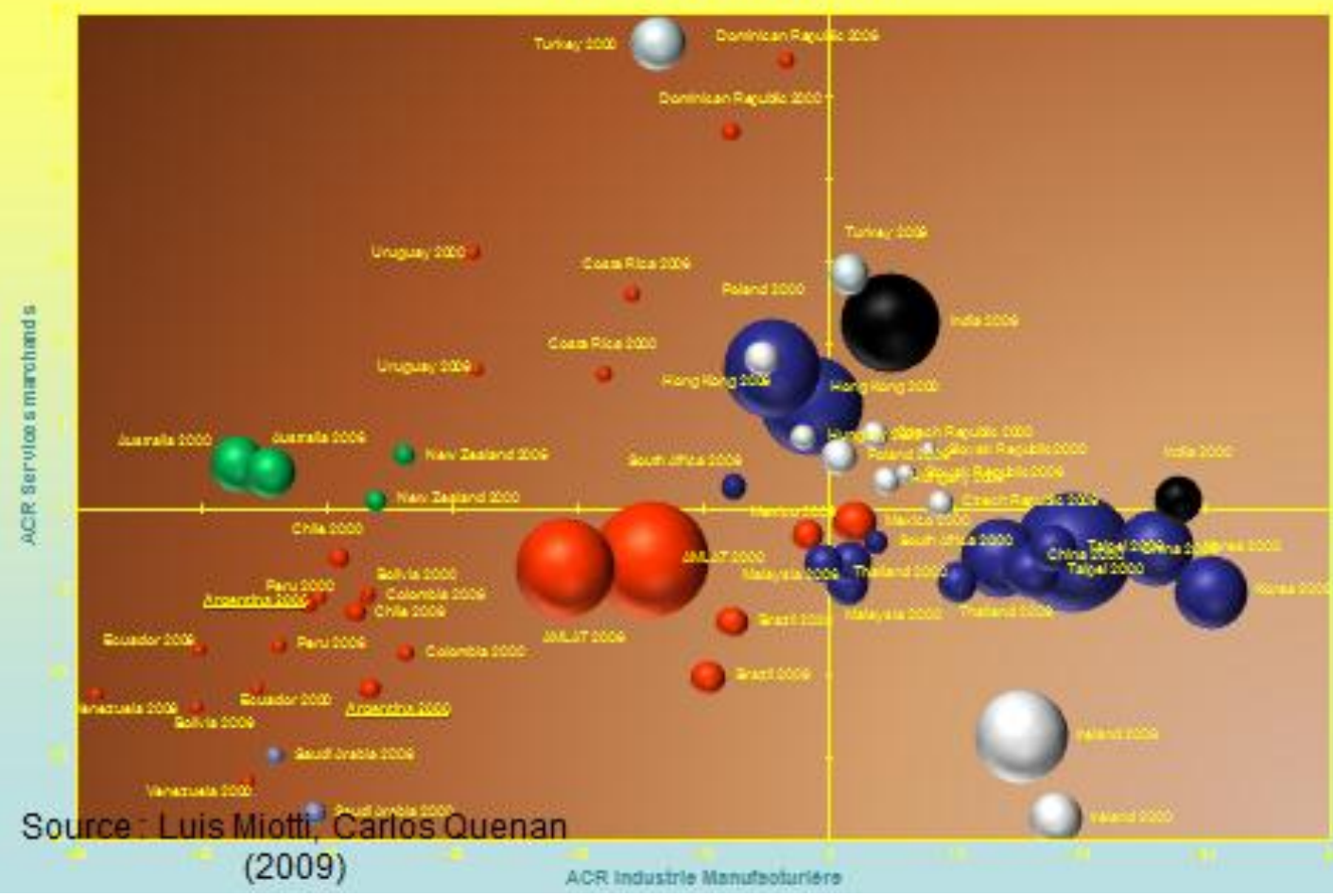

Source: Miotti, Quenan, Torija Zane (2012)

Figure 6: The adverse impact of internationalization and financial liberalization upon macroeconomic stability

Figure C3: Correlation between liberalization and

stability:the $2000 \mathrm{~s}$

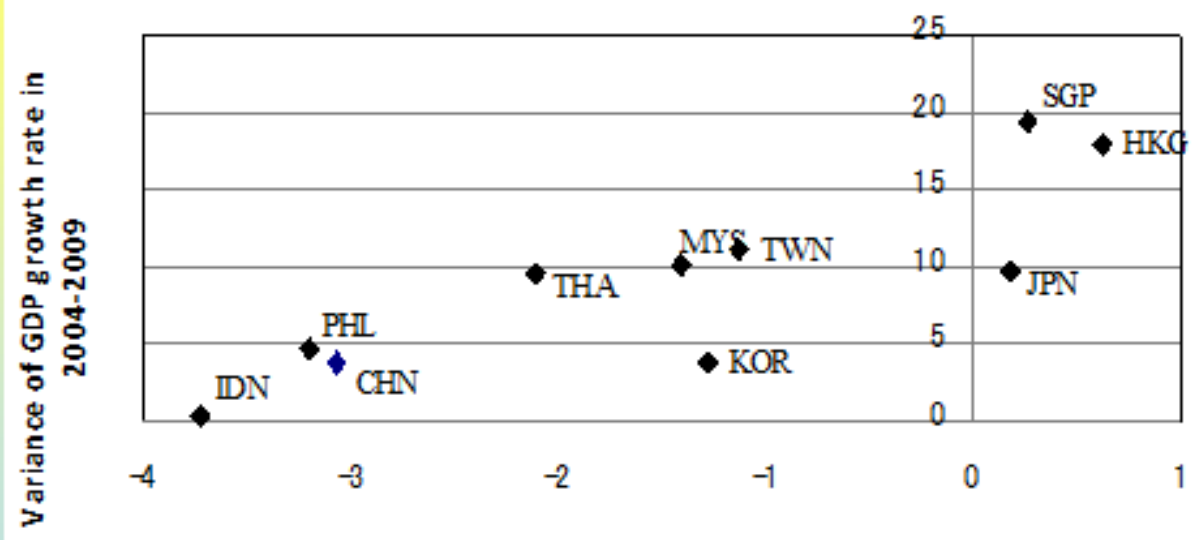

1st Factor (X axis) in Fig.13.5

Source: Yuji Harada and Hironori Tohyama (2011) 
Figure 8: Poor Asian countries are financing the consumption and even speculation in the US

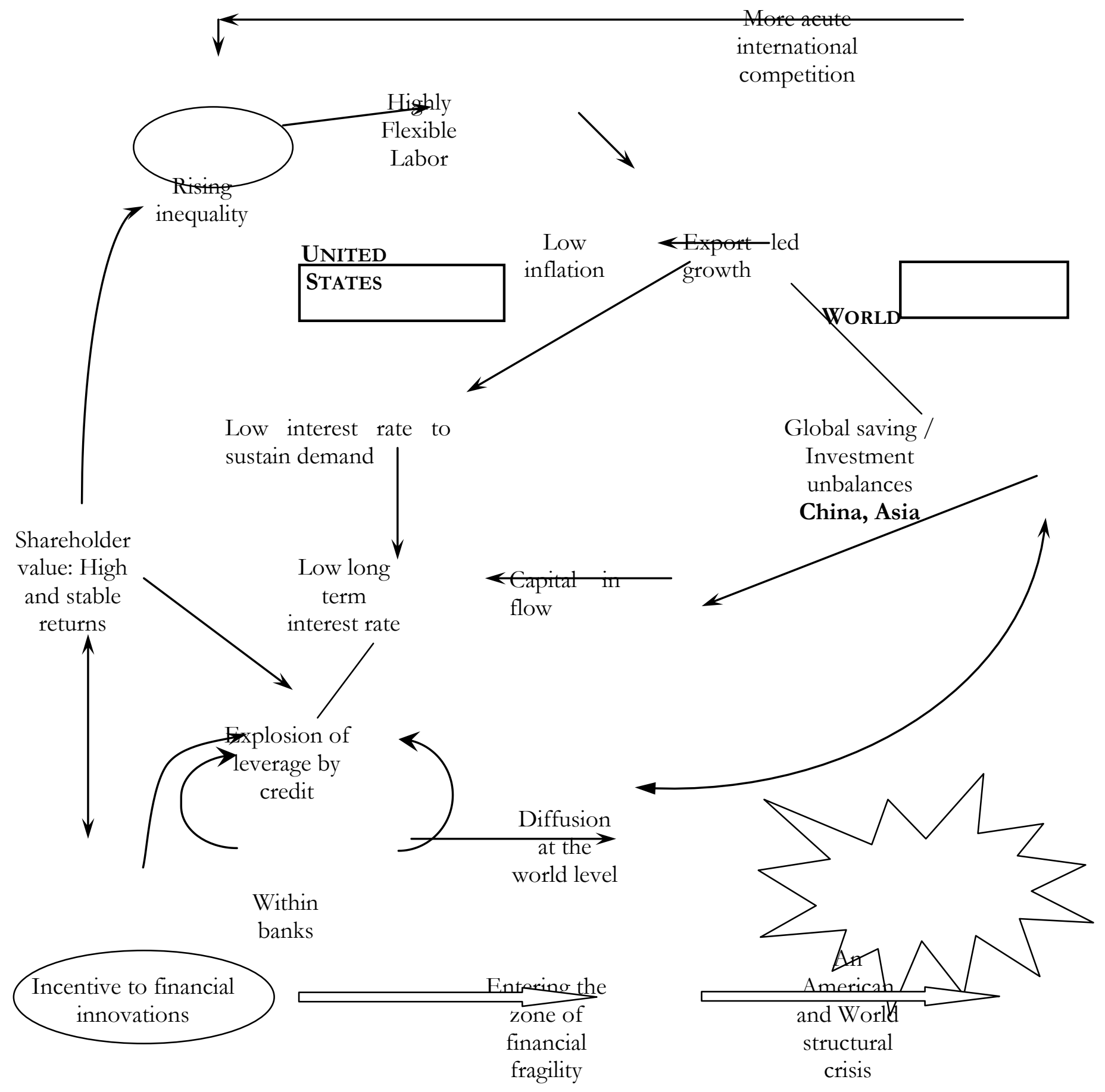

Source: From Christopher Adam and David Vines (2009) 
